\title{
"A Weekly Mäshräp to Tackle Extremism”: Music-Making in Uyghur Communities and Intangible Cultural Heritage in China
}

\author{
RACHEL HARRIS / SOAS, University of London
}

\begin{abstract}
This article provides an in-depth study and critique of the nomination and inscription of an item on UNESCO's lists of intangible cultural heritage and the developments following its acceptance. China is now a major partner in UNESCO's heritage projects, but the application and experience of heritage initiatives across China have been highly uneven. I discuss the particular challenges presented in the contested, predominantly Muslim Xinjiang Uyghur Autonomous Region. I focus on the question of community, a term that lies at the heart of the UNESCO literature. What do we mean by community, and why do we think it matters? How does socially embedded music-making facilitate community, and how do heritage initiatives change that?
\end{abstract}

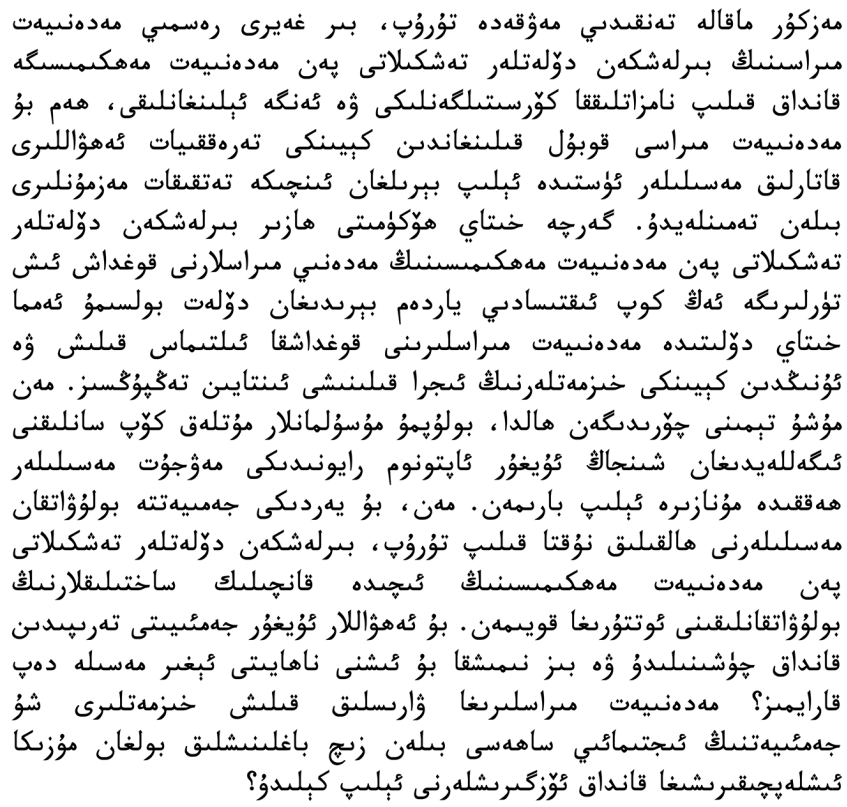

(C) 2020 by the Society for Ethnomusicology 
本文深入研究并评论了联合国教科文组织对一项非物质文化遗产的提名和认定, 以及其后

的发展状况。中国现在是联合国教科文组织非遗项目的重要合作伙伴，然而中国各地非遗

项目的实施和经验却严重不平衡。我在此讨论的是以穆斯林为主要人口的新疆维吾尔自治

区这一争议地区在这方面遇到的特定挑战。我聚焦于社群, 这也是联合国教科文组织的文

献中的核心词语。我们谈到社群的时候指的是什么? 我们又为什么认为它很重要? 处于社

会语境中的音乐活动是如何对社群起到促进作用的? 非遗项目又是如何改变这一过程的?

Tn 2010 China successfully submitted three more items to UNESCO's fast-

growing list of Intangible Cultural Heritage in Need of Urgent Safeguarding. Among them was the Uyghur meshrep (mäshräp), an item whose inscription I was involved with in the role of expert evaluator for UNESCO (Seeger 2009). ${ }^{1}$ Mäshräp can be found on the UNESCO website, described in the following terms: "a rich collection of traditions and performance arts, such as music, dance, drama, folk arts, acrobatics, oral literature, foodways and games. . . Meshrep functions both as a 'court,' where the host mediates conflicts and ensures the preservation of moral standards, and as a 'classroom,' where people can learn about their traditional customs."

During the next few years, representations of this cultural practice achieved remarkable prominence in the public arena in China's Xinjiang Uyghur Autonomous Region (XUAR). Xinjiang's song-and-dance troupes developed staged versions of mäshräp, which were screened monthly on Xinjiang's TV stations. Academic and popular publications on mäshräp in both the Uyghur and Chinese languages and box sets of DVDs were sold in the region's official bookshops. The label "mäshräp" was used to market a range of venues and commodities from restaurants to household appliances to toilet paper, part of the "halo effect" of UNESCO recognition noted by Tim Taylor (2017:153). Such developments indicate not only strong state support but also a surge of Uyghur national pride in this tradition. But what has the impact of this safeguarding initiative been on its ostensible target: grassroots mäshräp practices among Uyghur communities? In this article, I discuss my experience of mäshräp prior to its inscription as an item of intangible cultural heritage in urgent need of safeguarding, the dilemmas I faced as an evaluator, and my observations of the situation of mäshräp since it was inscribed. 


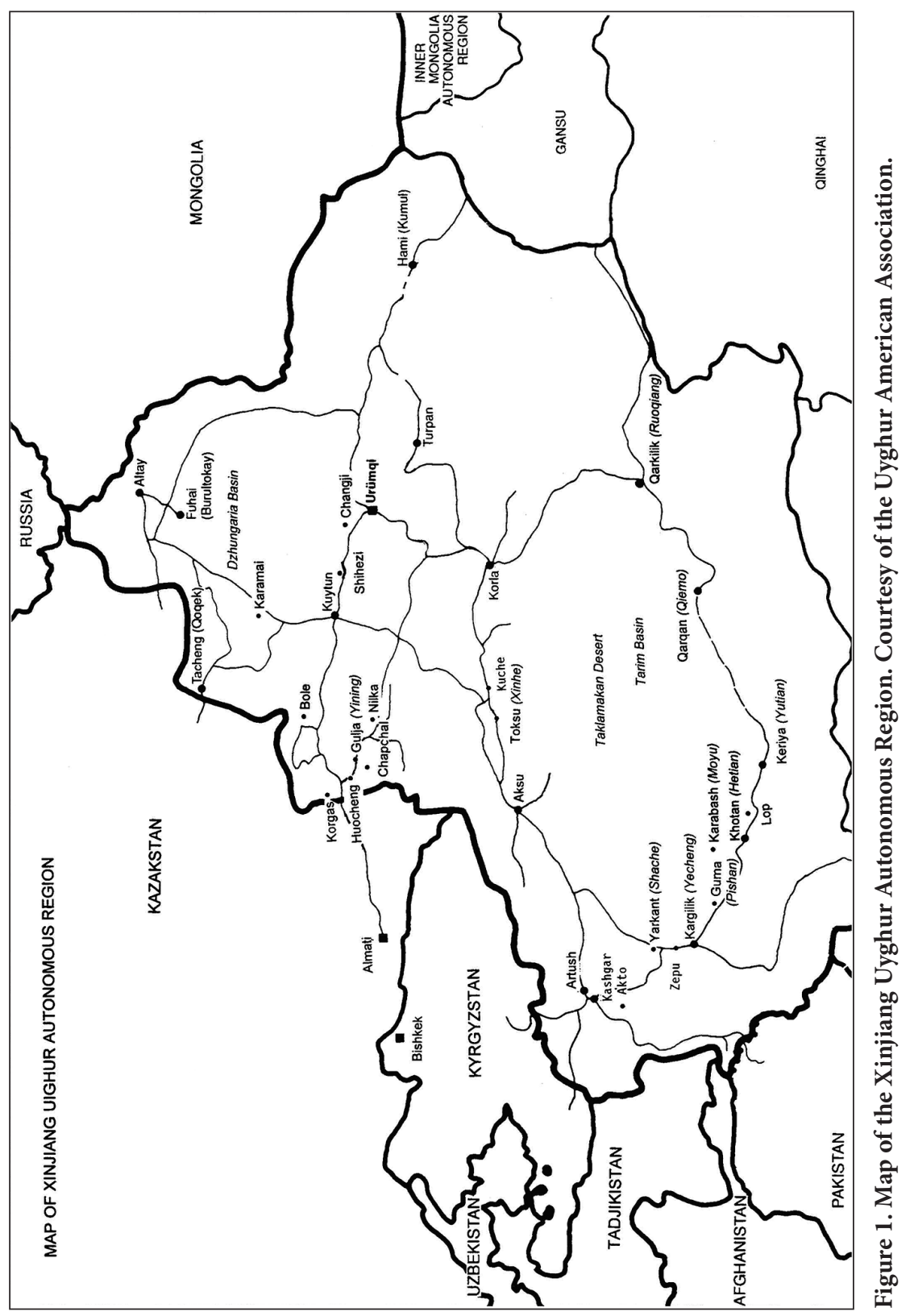




\section{Music and Community}

The term "community" is perhaps most commonly used to refer to immediate, lived social relations and is opposed to the larger notion of "society," but none of these terms are easily defined or bounded. Anthropologists suggest that community does not map simply onto a geographical place; instead, it is a process, a series of everyday practices engaged in by a group of people. Communities also participate in wider social fields and are caught up in flows of capital and state power. Much critiqued in recent years, the term-as Kay Shelemay has argued-has been "frozen at the juncture of competing theories of location, mobility, identity, and politics, becoming in the process so ambiguous that to use the term is to be confronted with the necessity to argue for its use" (Shelemay 2011:9). As Brett Williams notes, usages of community today might entail anything from categories of difference to transnational practices, from political consciousness to rallying around cultural symbols: "No matter what kind of community a community is, it is always a claim, a fiction, inscribed through symbols, ceremony, food, or a set of practices. It is almost always a site of disengagement and struggle as well as attachment and belonging" (2002:348).

Vered Amit and Nigel Rapport $(2012: 3,14)$ argue that this ambiguity in the idea of community is productive. They critique the tendency in the anthropological literature that situates community in the extraordinary (Victor Turner's [1969] "communitas") and emphasize community as an idea (Benedict Anderson's [1991] "imagined communities"), a tendency that takes away from its usefulness as a framework for interrogating substantive social relations. Amit and Rapport propose a new framework for approaching community, one that emphasizes community as a distributive model of belonging and affect. This model is helpful when we think about the role that expressive culture might play in producing and sustaining community.

Shelemay calls for a specifically musical rethinking of the notion of community in order to explore musical transmission and performance as "an integral part of processes that can at different moments help generate, shape, and sustain new collectivities" (2011:1). Notions of community, and the role of music in sustaining it, are in fact central to many mainstream statements in ethnomusicology. Thomas Turino, for example, notes the special properties of music and dance that make them fundamental resources for connecting communities. These properties allow people to

intimately feel themselves part of the community through the realization of shared cultural knowledge and style and through the very act of participating together in performance. Music and dance are key to identity formation because they are often a public presentation of the deepest feelings and qualities that make a group unique. Through moving and sounding together in synchrony, people can experience a 
feeling of oneness with others. The signs of this social intimacy are experienced directly - body to body — and thus in the moment are felt to be true. (Turino 2008:2-3)

In a similar vein, Jeff Todd Titon (2015) proposes the notion of a "sound community" to refer to a community established and maintained by acoustic communication and also by extension a healthy and resilient community. For Titon, copresence in sound is intersubjective and relational, a subject-to-subject resonant and reciprocal way of knowing, participatory and exchanged freely, and this is central to its role in strengthening and sustaining communities. This mines a rich vein of utopian thinking in ethnomusicology, but it also dovetails neatly with more recent moves in anthropology that suggest how a focus more broadly on the sensorium may help to answer Shelemay's call, bringing recent moves in ethnomusicology together with developments in anthropology. In his study of temple fairs in rural China, Adam Chau, for example, emphasizes the active participatory role of social agents in the sensory production of sociality. Chau argues for a sensory-production model of analysis that foregrounds the active participatory role of social agents in producing a sensorily rich social world: "We may come to understand how people in a particular culture know and are in the world through the senses, but there has been little explicit attention to the active participatory role of human agents themselves in producing the said sensory stimuli" (2008:488). In this view, sensorily rich activities like joking, playing games, and musicking are always social and relational. They coproduce a sensorialized sociality shared and enjoyed by all who are present, creating rich experiences of community in the moment of performance. This approach to sociality is key to understanding the way that music-making is embedded in a wider range of activities and experiences produced during a mäshräp and to understanding the role of Uyghur mäshräp in producing and sustaining community.

\section{Uyghur Communities}

We may view the Uyghurs as one of China's officially recognized minority nationalities alongside, for example, the Tibetans or Mongols or, alternatively, as one of the Central Asian nationalities (nations) alongside, for example, the Uzbeks and Tajiks, the only one of these nations that does not possess its own independent nation-state. ${ }^{3}$ Culturally, the Uyghurs are Central Asian, but their homeland lies within the borders of the People's Republic of China in the large desert and mountainous region of northwestern China widely known as Xinjiang. Uyghurs follow Sunni Islam of a kind strongly influenced by Sufi traditions, especially practices of shrine pilgrimage and forms of sama' ritual gathering. ${ }^{4}$ They are speakers of a Turkic language that is closely related to Uzbek, and 
Uyghur musical traditions are closely related to the neighboring musical cultures of Central Asia. Some eleven million Uyghurs live in Xinjiang, according to the latest census, and there are also sizable populations in the neighboring Central Asian states of Kyrgyzstan, Kazakhstan, and Uzbekistan, as well as in Turkey, Europe, America, and Australia.

The term "community" is most closely translated in Uyghur as jämä̈t, which suggests primarily the mosque community, a hierarchical system dominated by respected and pious older men. This overlaps with geographical units, the village (yeza) or neighborhood (mähällä), and the dense networks of reciprocity (hospitality, sharing food, mutual assistance) that are actively maintained by women with their neighbors and extended family (Bellér-Hann 2008). Uyghur communities in Xinjiang have experienced significant levels of change, mobility, and rupture over the past century: unrest and war, incorporation into the People's Republic of China in 1955, land reforms and communization, the rise of an educated middle class and ethnic nationalism, and the chaos of the Cultural Revolution (Bovingdon 2010; Brophy 2016). Peasants regained some control over their land in the 1980s, but a heavily interventionist state apparatus continues to dictate what crops are grown and requires them to engage in the khasha (compulsory labor; see Bellér-Hann 1997). The large-scale development and urbanization of the 1990s impelled a massive influx of Han migrants into the region; Uyghurs now comprise just over 50 percent of the total population of Xinjiang, according to the latest census. Development and urbanization also impelled significant Uyghur rural-to-urban migration and sometimes the wholesale movement of local communities to new sites to facilitate development projects (Bellér-Hann 2014). Alongside these changes impelled by development and urbanization, an Islamic revival also began to grow in force in the 1990s (Harris 2013; Smith Finley 2013), and Uyghur villagers began to engage in the construction of new forms of community that were often transnational and technologically mediated (Harris and Isa 2011). State attempts to counter this rise in religious piety and closer links between Uyghurs and the Middle East took the form of a series of increasingly repressive and violent "antiextremism campaigns," which progressively banned mainstream forms of religious expression and practice, including reading religious books (including the Qur'an), religious styles of clothing, the Ramadan fast, daily prayers, and mosque attendance. These policies triggered a series of violent incidents that China's state media was quick to label as extremist terror (Roberts 2018). This culminated in the declaration of the "People's War on Terror" in 2016, which introduced unprecedented levels of surveillance and detention, with an estimated 1.1 million Uyghurs incarcerated in "reeducation centers" at the time of writing. ${ }^{5}$ Alongside these policies, the local authorities also introduced forms of "reeducation" for the wider Uyghur population that included compulsory singing and dancing sessions designed to "counter extremism" (Harris 2017). 
In short, Uyghur communities are precarious and in a state of flux. Their current situation has become critical, but throughout the twentieth century they have engaged in a constant process of rebuilding and reformulating in the face of rapid social and economic change, incorporating new practices and reimagining established practices of sociality, always in negotiation with state policies. Amid all this rapid change, Uyghurs have maintained forms of community primarily in the form of social ties sustained through hospitality and celebrations, including weddings, circumcision parties, and (when permitted) religious festivals. Mäshräp, as we will see, play a prominent role both in modern imaginings of Uyghur identity and tradition and in these more fundamental processes of community-making. Mäshräp are sites for acts of reciprocity and for the transmission of social rules and norms, but they are also contexts within which community is enacted through forms of expressive culture, including music and dance.

\section{Local Traditions of Mäshräp}

A diverse set of social contexts and meanings is subsumed under the term mäshräp. Among Uyghur men from the Ili valley in the northwest of Xinjiang, monthly mäshräp gatherings, structured around musical performance, stories and jokes, and informal court hearings, have been the expression of lasting social bonds between groups of men who are termed the ottuz oghul (thirty sons). The mäshräp held in the town of Ghulja in the mid-twentieth century nurtured a group of musicians who would be instrumental in formalizing the national repertoire of Uyghur music. According to singer Gheyazdin Barat (d. 2000), members gathered in a family home and took turns to host the mäshräp. Musicians were always invited; the host would give them a gift of clothes or cloth, and dancers placed money in a tray set in front of the musicians. There should be three periods of dancing in the course of a mäshräp, one time to listen to the muqam, one time for stories and jokes, one time for songs, and one time for quiet when members could report which of their peers had committed some fault. The punishments were severe, he said, and people usually only had to be punished once (Gheyazdin Barat, interview with the author, April 1999).

The Ili mäshräp served to teach the rules of communal behavior to young men and enforced them through the mäshräp's informal court. They also served as a way to perform and transmit expressive culture and communal knowledge. They were "a rite of passage into manhood, a vehicle for teaching and regulating moral, religious, and social etiquette, and a means of forming male peer groups" (Roberts 1998:675). Uyghurs in the Ili valley use the phrase "mäshräpni körmigän bala" (a boy who has not seen a mäshräp) to refer to a young man who is deemed uncouth. When a young man is first introduced into a mäshräp group, his father or representative says to the ottuz oghul, "The boy's skeleton is ours, 
but his flesh is yours; teach him morals and manners, for I have brought him to the mäshräp" (682). This phrasing recalls rituals of apprenticeship, including musical apprenticeship, that were also exclusively male. This form of mäshräp was an exclusively gendered site for the production of communal masculinity, involving the acquisition and exercise of power, responsibility, and mutual aid.

These Ili mäshräp have been a major force in retaining Uyghur identity and culture in the diaspora. In 2003 in the Kyrgyz capital of Bishkek, I attended a mäshräp held by a group of migrants who came from Ghulja in the early 1960s. This group of ottuz oghul claimed proudly that they had held their mäshräp continuously for forty years. They maintained the traditional rules, presided over by the yigit beshi (leader of the lads) and qazi (judge), and administered punishments such as the "surutini tamghur tartish" (shadow on the wall, during which water is thrown over the guilty party). The yigit beshi and qazi were also the leading musicians in the group and played muqam on violin and dutar. Their wives and children labored over the immense meal inside the house and appeared only to serve the food, but feminine representations were not absent from the performance; one of the ottuz oghul gave a spirited demonstration of a coquettish dance complete with a tea bowl balanced on his head.

In southern Xinjiang, the fixed mäshräp fraternity structure of the ottuz oghul is not practiced; instead, mäshräp are organized along the lines of hospitality and reciprocity that more generally characterize social relations in Uyghur society. Ildikó Bellér-Hann describes mäshräp as "the institutionalized enactment of community itself; through the transmission of rules between generations young people were taught how to be social, how to submit to the rules of the community" (2008:215). In the south, women and men actively participate in mäshräp. As in the Ili valley, games, music, and dancing are central, and the mäshräp also serves as an informal community court, which here again is often officiated by the musicians. In a Dolan Uyghur village near Kashgar, I attended a mäshräp where the musicians played the role of clowns at the same time as they meted out justice. ${ }^{6}$ Lapses in morality were punished by ritual humiliation, to the delight of the crowd. Here too I found gender reversal for comic effect: one man was "fined" for flirting by being "married to two wives" in the form of two mincing musicians in women's head scarves who lay on each side of him on a makeshift bed in the middle of the dance arena and took turns smacking his face. ${ }^{7}$ The gathering culminated with a distinctive competitive whirling circle dance from which dancers gradually dropped out, tired or dizzy, until one winner was left in the arena performing high victory leaps.

This Dolan mäshräp was clearly a thriving, locally maintained tradition, though already managed to some degree by the local authorities. Häkhät Tokhti, who played the Dolan rawap lute and acted as chief clown, told me in 2000 that they were playing at four or five mäshräp in a week. He also farmed a plot of 


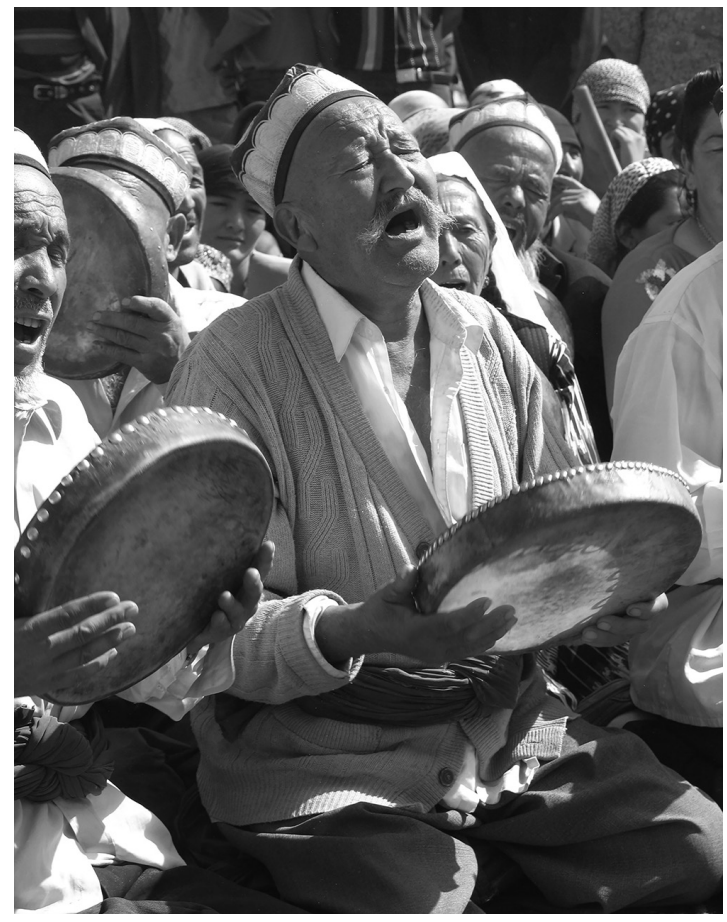

Figure 2. Singing the Dolan Muqam at a mäshräp. Courtesy of Rahile Dawut.

land, growing "whatever the authorities tell me to grow," but his music was an important source of income. A group could earn 200 to 300 RMB (equivalent to a week's wages) at a mäshräp, depending on how many people attended; as Gheyazdin Barat also reported in Ili, the money is given to the musicians by the dancers. Another important benefit for the musicians was that they could avoid the khasha obligatory labor. Instead, musicians could be called on at any time by the local authorities to play for visiting officials and guests (Häkhät Tokhti, interview with the author, Yantaq, July 2000).

Since 2010, this particular village mäshräp and its related musical tradition, the Dolan Muqam, has become the object of extraordinary promotion (figure 2). ${ }^{8}$ Some of the musicians who performed there now teach and perform with the Xinjiang song-and-dance troupe; they feature in several Uyghur pop music videos; their performance of the Dolan Muqam has been published in multiple forms within China and released on CD by the French label Inedit; their mäshräp have been filmed and recorded perhaps hundreds of times and are frequently shown on regional and national Chinese television; and they have performed in concert halls and music festivals around the world. How did this all come about? 


\section{Intangible Cultural Heritage in China}

The dizzying set of life changes undergone by those musicians began in 2005 when “The Art of Uyghur Muqam in Xinjiang” appeared on UNESCO's List of Masterpieces of the Intangible Heritage of Humanity, a program subsequently superseded by a set of new lists: the Representative List and the List for Urgent Safeguarding, on which the "Uyghur Meshrep" appears (Seeger 2009; Foster 2015). This period marked the beginning of a new discourse in Xinjiang under which selected traditional cultural practices were reframed as intangible cultural heritage. This discourse drew on the guidelines developed by UNESCO and was mediated by the existing Chinese discourses on "national traditions."

The Convention for the Safeguarding of Intangible Cultural Heritage was adopted by UNESCO in 2003 after many years of negotiations and expert consultations, the most recent in a long series of UNESCO policies concerning heritage both "tangible" and "intangible" (Foster 2015). It aimed to accord greater value to cultural traditions and practices, among them music, festivals, rituals, and cultural spaces, characterized in UNESCO literature as "fragile and perishable but essential for communities' cultural identity." Under this carefully devised and hotly negotiated framework (Seeger 2009), heritage was regarded not as fixed and static tradition but as something permanently evolving, encompassing not only rural traditions but also urban and hybrid cultures. The guidelines placed emphasis on the individuals who embody the skills and techniques that maintain the traditions and the communities in which they participate. Earlier models of approaches to heritage developed in Japan and Korea were influential on this new UNESCO formulation (Howard 2012). The program sought to raise awareness and recognize the importance of intangible heritage, and it also stressed the need to safeguard and revitalize that heritage. Each submission for heritage status should include an action plan for revitalization, safeguarding, and promotion; the plan will be scrutinized by UNESCO-appointed experts and assessed by an international jury. ${ }^{9}$

China participated enthusiastically in the process from the start, and a substantial academic literature devoted to "heritage with Chinese characteristics" is now available (Silverman and Blumenfield 2013; Kuah and Liu 2017; Svensson and Maags 2018). By 2017 a total of thirty-nine Chinese items had been inscribed on the various UNESCO lists, while China's own list of national-level intangible heritage items ran to an impressive 2,438 items. ${ }^{10}$ In Xinjiang, these include the Kyrgyz Manas epic, the Kazakh dombra, and the "Tajik" game of buzkashi, among many others. ${ }^{11}$ Across China, local efforts to get cultural items included on the national list produced an upsurge in surveys, training handbooks and classes, and archiving initiatives. Successful applications were rewarded with generous state funding for preservation plans, which included research, 
archiving, conferences and publication, and stipends for designated representative transmitters to transmit their art (Rees 2012:31). Daily media attention was devoted to the subject, specialist magazines were published, and there was widespread interest and debate among cultural practitioners, local bureaucrats, and commentators. The enormous enthusiasm for intangible cultural heritage displayed by Chinese government organs and state media suggests that as early as 2005 it had become a major plank of cultural policy. Commentators have argued that this new role as protector of national heritage formed a part of the Chinese Communist Party's search for new forms of legitimacy beyond communism. It was, of course, an extraordinary historical shift away from the massive destruction of heritage under the policies of the revolutionary era just a few decades earlier (Chang 2017).

In other ways, however, there was considerable continuity with the practices of the revolutionary era. The aesthetic norms of professional, staged folkloric performance established in the mid-twentieth century have continued to dominate representations of intangible heritage in twenty-first-century China. Isabel Wong writes that the 2001 listing of Kunqu opera on the UNESCO Masterpieces List was taken as "official encouragement to give Kunqu a globalized veneer. ... $[\mathrm{N}]$ ew and lavish stage productions were produced with simple stories or little singing, but with lots of action, to attract foreign audiences in China and abroad" (2009:31). When the Uyghur Muqam joined Kunqu opera on the UNESCO Masterpieces List in 2005, although the nomination file devoted considerable attention to locally maintained traditions, in practice, staged performances by the Muqam Ensemble and Xinjiang song-and-dance troupe continued to dominate the national sphere, while the "representative transmitters" of regional Muqam traditions were extracted from their local communities and brought to Ürümchi to participate in the work of transforming their own repertoire and practice to conform to the aesthetic framework of the established troupes (Harris 2008).

In terms of the political agenda too, statements issuing from central government suggest much continuity with established agendas behind the promotion of folk art, with a notable shift away from UNESCO's emphasis on communities toward national identity and national unity, as an important 2006 speech at a Beijing exhibition made clear: "The protection of intangible cultural heritage and maintaining continuity of the national culture constitute an essential cultural base for enhancing cohesion of the nation, boosting national unity, invigorating the national spirit, and safeguarding national unification." ${ }^{12}$ Jung-a Chang (2017:121) also describes how Chinese theories of heritage align with current political campaigns, highlighting, for example, the contributions of intangible cultural heritage to the "harmonious society" (a key slogan during the 2000s) and the possibilities for its use as an educational tool for fostering patriotism. 
Official support for cultural heritage generally centers on the elements that are most directly aligned with party priorities (Silverman and Blumenfield 2013:4).

Heritage, not only in China but throughout the world, is a tool of governance. It can be used to control and manage tradition, cultural practices, and religion and to steer people's memories, sense of place, and identities in particular ways, providing a softer and less visible way of rendering individuals governable (Svensson and Maags 2018). There is substantial investment in heritage at all levels of society and government in China. The national government sees participation in the heritage domain as an aspect of soft power on the national and international stages; county governments see heritage as economic capital, especially in its potential to attract tourism; and local actors invest strongly in intangible heritage as social and cultural capital (Kuah and Liu 2017:6). As this last point suggests, a narrow emphasis on government policy cannot fully explain the massive popularity of this initiative and the radical shift in public attitudes it has entailed, from the position in the 1980s where Chinese cultural traditions were routinely disregarded or denigrated to what Helen Rees terms a "juggernaut of initiatives and impassioned calls for protection" (2012:53). The widespread change in attitudes can be linked to the upsurge in Chinese nationalism and competitiveness at the international and regional levels but also to the sense of cultural dislocation and nostalgia engendered by China's rapid urbanization and social development (Rees 2016; Chang 2017). The government's nationalist rhetoric and rediscovery of heritage sites and practices find a deep resonance among many people in China who are troubled by a perceived erosion of social values and cultural traditions (Svensson and Maags 2018:14).

There is ample scope for disconnect between UNESCO_that massive international organization headquartered in Paris—and the small disparate communities scattered across the globe that are targeted by its efforts and affected by its decisions. Michael Foster (2015:143-44) has argued that UNESCO's metacultural policies often become a testing ground for negotiations between the global and the local. Studies of heritage in China have begun to pay attention to the ways in which local residents participate in, respond to, and even manage to shape cultural policies within their own communities, often against the backdrop of a very top-down official framework (Kuah and Liu 2017). Case studies (You 2015; Liu 2017; Ong 2018) suggest the very heated nature of these debates and disagreements and the very uneven terrain in terms of the possibilities for negotiation. Marina Svensson and Christina Maags (2018) note the great diversity encompassed in discussions of heritage in China in terms of regional, cultural, and ethnic differences, as well as the significant gaps between "heritage professionals" and the general public. A key question in studying Chinese approaches to heritage is to consider the relative possibilities for negotiation and contestation over heritage to flourish in different regions at different historical moments. 


\section{Minority Nationalities and Intangible Cultural Heritage}

Ethnic minority cultural practices, especially musical genres, have featured disproportionately in China's selected masterpieces: thirteen of the thirty-nine items on UNESCO's lists. This emphasis reflects the long-standing prominence and political manipulation of minority arts in Chinese national culture, as well as the geographical position of minority peoples in regions whose regional governments see tourism as a vital part of their development strategies (Svensson and Maags 2018). Some commentators have been quick to note how the Chinese promotion of minority traditions stresses their "inalienable identity" as a part of China and suggest that China's preference for promoting intangible heritage items as symbols of identity was because their meanings and presentation were easier to manipulate and control than those of physical heritage sites. ${ }^{13}$ Helaine Silverman and Tami Blumenfield (2013:8) argue that the chief goal of China's heritage and tourism policies is to incorporate minority ethnic regions more firmly into China. While cultural policies promote minority distinctiveness, the state is both vigilant and active in suppressing those whom it views as threatening the unity of the nation or its goals of modernization. Other observers take a more optimistic view. Rees, for example, notes the transformation of the Naxi Dongba ritual in Yunnan as the official view of this practice shifted from "feudal superstition" to "cultural asset." Government officials stopped harassing its practitioners and began enthusiastically promoting its inclusion in international festivals (Rees 2012:43; see also McKhann 2010). More common is for the rituals to undergo a "heritagization process" through which they are reconstructed and reinterpreted, often with their religious aspects downplayed or ignored (Svensson and Maags 2018:19).

An ethnographic study of the impact of heritage programs on Kam (Dongzu) society in southwestern China is instructive (Ingram et al. 2011). In recent years, Kam Grand Song (Dongzu da'ge, polyphonic song traditions of the Kam people) has been heavily promoted as an item of intangible heritage and brought into the sphere of staged performances for tourists, national media, and international tours. Ingram argues that the initiative was undertaken without appropriate consultation and has encouraged the commoditization of the song culture: "Many Kam women are aware of the ways that the cultural development of staged Kam song performances essentializes and exoticizes Kam people, and know that Kam people's participation in staged song performances brings certain political and economic benefits to state agencies without always directly benefitting the Kam people involved. However, women still collaborate in the performances for other strategic reasons, such as to increase their own cultural, symbolic and economic capital within the local arena" (Ingram et al. 2011:80). While there is no indication that its design was actually intended to do so, cultural development has in 
practice led to greater agency for these women. Case studies such as this remind us that the heritage projects cannot be seen as inherently beneficial processes, but neither should ethnic minority practitioners be seen as powerless in their participation within them.

\section{Mäshräp: The Inscription Process}

An account of the application process published on the Chinese Academy of Social Sciences website lays out a detailed hierarchy of responsibility for the application:

On 8 March 2009 the Ministry of Culture of the People's Republic of China submitted China's Xinjiang Uyghur mäshräp to UNESCO’s list of Intangible Cultural Heritage in Need of Urgent Safeguarding. Prior to this, the vice chairman of the Eighth and Ninth NPC, Tomur Dawamat, the Ministry of Culture of the State Council, the Central People's Broadcasting Station, CCTV, many media reporters, the Xinjiang Uyghur Autonomous Region party and government leaders, the director of the Xinjiang Cultural Bureau, Abulizi Abudureyimu, and the team that had primary responsibility for the Xinjiang mäshräp inscription work made unremitting efforts and hard work, received strong support from the party committee, government, and all the peoples of Xinjiang, and made an indelible contribution to the mäshräp inscription work. ${ }^{14}$

In other words, this project was about as top-down as it gets; but also, significantly, it was driven and implemented predominantly by Uyghurs. Tomur Dawamat, chairman of the Xinjiang Uyghur Autonomous Region from 1985 to 1993, had nurtured this project since participating in an ICH Congress in Beijing in 2003. Under his leadership, a series of archiving and publication initiatives were set in motion that would pave the way for the state submission to UNESCO. A mäshräp rescue team was established with the purpose of carrying out rescue and safeguarding measures, including the nomination of three local mäshräp traditions for inscription on the national list. Xinjiang media increased their coverage of mäshräp, and Xinjiang's universities listed mäshräp among their designated research subjects.

The Xinjiang ICH Protection Center played a significant role in the process. This organization grew out of the Xinjiang Arts Research Unit, which was responsible for the Xinjiang part of the 1980s government initiative to document the musical traditions of the nation in the massive multivolume series, The Anthology of Chinese Folk Music. ${ }^{15}$ Under this project, its researchers traveled across the Xinjiang region, recording and interviewing musicians. They spearheaded the earlier successful submission of the Muqam to UNESCO, and they were a natural choice to be involved in this new submission. Uyghur academics were also drawn into the process, publishing a series of fieldwork-based accounts 
of mäshräp in Chinese (Maimaiti 2006) and Uyghur (Abliz 2009; Dawut and Muhpul 2011).

On the basis of this accumulated knowledge and coordinating with local cultural offices, the submission work group set about planning the principal publication for their initiative: a set of thirty-one films of local mäshräp (Junggu 2008). These films are fascinating texts. Each selected locality brought out the best of its expressive culture for inclusion in the mäshräp project, including performances by the local cultural troupe, comedians, storytellers, and village musicians and dancers. They include some wonderful examples of local expressive culture-leper theatrical skits involving comical cross-dressers, a whirling sama' dance accompanied by some fascinating rhythms beaten out on huge frame drums, the extraordinary pantomime of the ghaz usuli (goose dance)all rubbing up against some terrible staged kitsch. These disparate items were stitched together to conform to a loose mäshräp structure designed to fit each forty-five-minute video, including staged court hearings and comical punishment scenes.

The videos are clearly scripted and rehearsed. They are filmed in a variety of settings, often against what seem to be specially constructed theater sets. The videos juxtapose professional with local amateur performances, sometimes to the extent that the visual shots of massed crowds of local musicians are overlaid with more "refined" studio recordings by the professional troupes. In this way, each of the thirty-one designated local mäshräp was fixed and given a unique appropriate name with local significance and its own overarching unique identifying characteristic. According to the state submission, "The Namakul [Apology] Maxirap [Mäshräp] is held to mediate conflicts or settle disputes; the Keiyet [Disciplinary] Maxirap is performed with the aim of criticizing immoral behaviors or educating the public; the Dolan Maxirap is meant to show admiration for the hunting life and bravery of the ancestors; and the Ketaphan [Storytelling] Maxi-

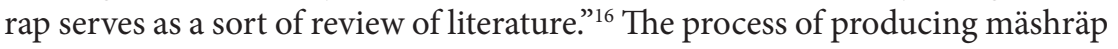
for submission to UNESCO recalls in many ways the processes of canonization of the Uyghur Muqam that preceded it. I read these films as acts of bricolage, which, as Philip Bohlman (1988) has aptly said, precede and enable projects of enshrining "things that people do" as "national culture."

Video clips were selected from the thirty-one DVDs for inclusion in the draft submission to UNESCO. Along with all the other items intended for submission in that year, they underwent a process of consultation at the national level. The Beijing-based heritage experts at the China Academy of Arts evidently shared some of my own reservations regarding the videos: "On 20 December 2008 experts on the National Expert Committee reviewed the material and made several recommendations. The experts considered that the submission video was too obviously staged, the participants were too obviously wearing 
makeup, the scenery was too flashy, and overall the content was too similar to the submission for the Uyghur Muqam." ${ }^{17}$ More attuned to the sensibilities that prevailed in UNESCO, the Beijing experts counseled a less obviously packaged and glossy presentation, but this advice was at odds with the dominant sensibilities in Xinjiang: as an item of culture that was to represent China's Uyghurs to the world, the mäshräp should look "developed" and "beautiful." Raw "peasant" culture was not fit to represent the Uyghur nation on the international stage.

Armed with these video productions, the mäshräp work team set to work to produce its written submission to UNESCO. The account of this process on the CASS website describes their anxieties over finding a suitable definition of mäshräp: how to strike the right balance between diversity and construct a clearly defined "item" for submission. The process of defining a distinct pan-Uyghur category of mäshräp, as opposed to other types of festive gathering, required some care.

In historical and contemporary accounts, mäshräp practices overlap with other named forms of gatherings: mäjlis (meetings) and bäzmä (feasts). The early twentieth-century missionary scholar Gunnar Jarring provides a description of the Snow Game, played after the first snow of the season, when a person would hide a written verse in a friend's home. If the friend found the verse before the person got back home, the author would be punished by being dressed as a woman and paraded around the streets; if he could not, then his friend must host a bäzmä. I have encountered similar games played among the Uyghur diaspora in the UK but termed Qar (Snow) Mäshräp. The celebration of spring in Qumul, today formalized among the thirty-one mäshräp as the Kök Mäshräp, is described in a 1930s Russian source as the Kök Mäjlis. Mäshräp may also refer to healing rituals: a 1950s source from Aqsu describes a Piri Mäshräp (pir may be glossed as "shaman" or "ritual healer"). Among the Dolan Uyghurs, a wedding party could also be termed mäshräp. In the early twentieth century, the term also referred to regular banquets organized on a rotating basis by members of guilds (Bellér-Hann 2008:210-14).

In their more informal incarnations, mäshräp also display considerable overlap with gatherings called olturush. In Ghulja in the mid-1990s, olturush took the form of men's drinking parties, held in the home or parks. According to Jay Dautcher's (2009:143-47) rich ethnography, these gatherings were the most important events in the day-to-day lives of many men in Ghulja. Men might attend several olturush in a week; they lasted six to ten hours and were rich in expressive culture, primarily joking and music. Like the mäshräp, they were subject to rules and were hosted by a saqiy, who served as leader, resolved any disputes, and poured the alcohol. Dautcher argues that they provided a path to establishing and maintaining social status in the local community. Diversity is key to understanding these practices: "This uncertain definition of the term, 


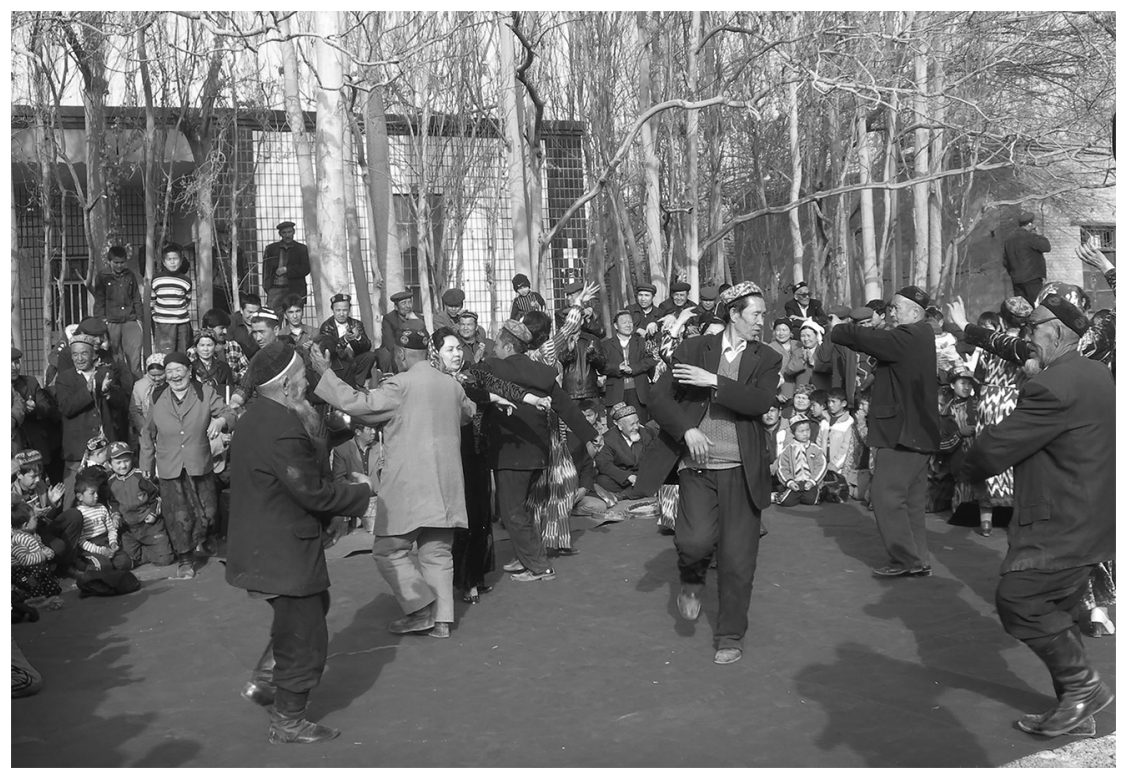

Figure 3. Dancing at a village mäshräp. Courtesy of Rahile Dawut.

which ranged from male socializing to religious assemblies including Sufi and other rituals, suggests that all these forms of sociability shared a number of features.... The term was so versatile because it indicated communal occasions of all sorts which remained outside the realm of 'mainstream' life-cycle and religious celebrations" (Bellér-Hann 2008:214).

\section{Healthy and Unhealthy Mäshräp}

The mäshräp submission to UNESCO was evidently based on excellent research and detailed local knowledge of mäshräp traditions around the region. But it is worth considering what aspects of these traditions are not foregrounded in the state submission. Mäshräp as a name also is shared by a seventeenth-century mystic poet, Bābā Rahīm Mashrab (Shah Mäshräp in the Uyghur pronunciation), who is a central figure in popular Sufism in Central Asia. Mashrab was a Sufi mystic poet, a qalandar who publicly violated conventional morality in order to bring people to a mystical understanding of God, one who transcended superficial obedience to doctrinal rules and knowledge of external appearances. The story of his life is contained in the Divinna-i Mashrab (Mashrab the madman), a set of stories and poems that circulated widely in written and oral forms across the places where he traveled: the Ferghana Valley (in contemporary Uzbekistan) 
and Altishahr (the "six cities" that ring the Taklimakan desert in today's southern Xinjiang). The pen name Mashrab, from the Arabic, means "place for drinking" and by extension came to mean a wellspring, particularly for Sufi inspiration. The contemporary usage of mäshräp as a term for gatherings and festivities may derive from and is certainly linked to Sufi gatherings (Light 2008:109-11). The word mäshräp also refers to a musical repertoire: the concluding section of the Twelve Muqam. This repertoire includes many songs that set the poems of Shah Mashrab. They form part of the repertoire of Sufi dervishes, known as ashiq or qalandar or sometimes as mäshräpchi, who perform them at shrine festivals, accompanying themselves on sapaya percussion sticks, surrounded by large crowds who listen to these performances as a way to acquire religious merit (Harris 2017).

The centrality of Islamic culture within mäshräp practices is also evidenced in the religious stories and texts that were frequently read aloud at these gatherings. Dautcher (2009:270-71) cites an account of mäshräp from 1870 that included reading aloud stories from the lives of saints and other Islamic stories and legends. Bellér-Hann describes how "popular Islamic texts by Rabğuzī, Jāmī, and Firdawsī, and the works of mystic authors, especially Yasawī, his disciple Sulaymān Baqirgan and Sūfī Allāyār, as well as stories about the various exploits of Muslim heroes descended from the Prophet 'Ali were recited. The recital was typically followed by dancing to musical accompaniment, which contributed to the Sufi character of such meetings, since similar dances were commonly performed by members of some brotherhoods" (2008:213).

The state submission to UNESCO effectively cleansed mäshräp of the religious aspects of its practice, presenting a purely secular version of the tradition. This move was a direct continuation of established PRC policy and practice on folk art; the Uyghur Muqam was similarly cleansed of references to its Islamic heritage when it was submitted to UNESCO. But in the case of the mäshräp, this process of cleansing took place within an immediate political context where Islam was coming to the fore as a mechanism for the assertion of Uyghur identity and community in ways that clashed directly and sometimes violently with the Xinjiang authorities. Moreover, one set of mäshräp practices was already directly implicated in this context.

The Ili mäshräp movement of the mid-1990s is characterized by Sean Roberts (1998) and Dautcher (2009) - both of whom conducted extensive ethnographic research with mäshräp participants-as an attempt by young Uyghur social activists to counter endemic problems of youth alcoholism, drug abuse, and crime through the propagation of a pious Muslim lifestyle. They arose in part in opposition to the well-established drinking culture of the olturush described above. These new Ili mäshräp displayed a great deal of continuity with the local tradition; they were organized around a fixed group of men, the ottuz oghul, 
who met regularly to discuss community issues, to promote Islamic practice, to regulate members' behavior, and to offer services to the community, such as gifts of cash or food to people in need. Punishments administered by the pashshap, typically for failure to maintain the regime of daily prayer or succumbing to peer pressure to drink alcohol, included räsim tartish (shadow on the wall [explained above]) but also beliq tutush (being forced to fish with the mouth for a heavy object in a pail of water), samsa berish (a slap on the face, just as a raw dumpling is slapped onto the side of the clay tonur oven), and ayropilan (being made to adopt the excruciating airplane posture, possibly a cultural borrowing from the struggle meetings of the Cultural Revolution; Dautcher 2009:273).

In July 1995 a group of mäshräp leaders initiated a boycott on alcohol in the town of Ghulja. Local officials, who were either unhappy about the loss of revenue for local state-run distilleries or feeling threatened by a form of community action they did not initiate, officially banned mäshräp gatherings. The movement, however, continued to flourish underground, with strong community support. In August 1995 mäshräp leaders organized a youth football league, again with a view to providing local youths with alternatives to drink, drugs, and crime. Teams were organized by the town neighborhood communities (mähällä) and became the object of much pride among residents. The authorities canceled the tournament and sent tanks to occupy the football field. Local residents marched past the field in a peaceful protest, and in response Ghulja was placed under martial law. Staged representations of mäshräp were already at this time being promoted within the tourism sector in Ili. They took the form, in Dautcher's words, of "sites of leisure and frivolity replete with boisterous games, singing maidens, and laughing children." In the aftermath of the demonstration, a filmed version of this state-promoted vision of mäshräp was screened on local TV, evidently with the intent "to present and promote a state-scripted meaning of mäshräp over the actual folk practice of the event" (Dautcher 2009:280).

These events formed part of the build-up to the "Ghulja Incident" of 5 February 1997, a day of intense protest and rioting, numerous arrests, and police shootings. The protestors marched in response to the announcement of a group of convictions on charges of extremism and separatism, and they reiterated their opposition to the banning of the mäshräp. They were condemned in China's state media as terrorists, and the state security forces were condemned by Amnesty International for gross violations of human rights, including the torture of detainees and large numbers of executions. ${ }^{18}$ In the immediate aftermath of the violence, Xinjiang People's Congress chairman Amudin Niyaz released a statement:

Mäshräp is a popular activity among the Uyghurs. However, a handful of national separatists, in order to realize their ulterior motive, have manipulated this recreation to establish illicit ties, using mäshräp as grounds for disseminating speeches, 
undermining national unity and motherland unification, and carrying out illegal religious activities.

This is absolutely not permissible. We must expose such tricks and conspiracies by refusing to participate in their kind of "mäshräp" and must crack down on such unlawful activity. Meanwhile, we must actively promote and organize the healthy, traditional mäshräp to enrich the masses' cultural and recreational life and to praise our new life, thereby promoting the advancement of Uighur culture. (translated by Dautcher 2009:285)

How is the distinction between "healthy" and "unhealthy" mäshräp made? The issue is not one of whether the mäshräp include any "religious extremist" or "separatist" activities-always nebulous charges-but rather who is in charge. At the heart of this is the question of the state's ability to tolerate free association and community-led initiatives in Xinjiang.

\section{An Evaluator's Dilemma}

In 2009 I was invited by UNESCO to act as evaluator for the nomination file "Maxirap," submitted by China. ${ }^{19}$ The file promised an action plan and considerable investment in safeguarding mäshräp, according to the following scheme:

1. To establish a mechanism for representative inheritors to safeguard and transmit mäshräp (1.2 million RMB)

2. Research and documentation (1.5 million RMB)

3. To establish zones of cultural preservation (4 million RMB)

4. To create a database $(400,000 \mathrm{RMB})$

5. To hold a conference ( 1.8 million RMB)

6. To train students in sustainable development $(450,000 \mathrm{RMB})^{20}$

Evaluators are asked to produce a detailed report on the nomination files, commenting on the viability of the nominated element and the feasibility and adequacy of the safeguarding plan, and a recommendation to the committee to inscribe or not to inscribe the nominated element. In view of the political context detailed above, the invitation posed a dilemma. Should the evaluator conclude that in such a context "safeguarding" this practice in the terms understood in UNESCO policy was unfeasible, or should the evaluator take the view that it was better to work with the system and hope that local players might be able use the initiative to bring about measurable benefits on the ground? In the spring of 2008 I was inclined to take the latter view. I recommended that the nomination should be inscribed, emphasizing the importance of mäshräp for local communities: "Mäshräp are important venues for the performance of locally maintained artistic traditions, primarily music (including folk songs and Muqam traditions) and dance. Participation in mäshräp demands a wide range of locally acquired knowledge, including ritual and religious, linguistic, custom and etiquette, norms of hierarchy and reciprocity, and play. As such they are key 
occasions which provide local communities with a sense of communal identity and continuity."

I also expressed reservations about the folkloric presentation of the mäshräp, in particular, the lack of reference to religious practice. My fellow evaluator, who was experienced in heritage matters but not closely acquainted with Xinjiang, recommended that the nomination should not be inscribed, citing some technicalities, and China was asked to resubmit. I was duly invited to examine the resubmitted file the following year. But at this point the July 2009 protests and subsequent interethnic violence in Ürümchi intervened (Harris and Isa 2011; Millward 2009). I was in Ürümchi at the time and experienced firsthand the violence on its city streets and the subsequent mass arrests and show trials, as well as the heavy police presence and restrictions on many aspects of life, including travel, gatherings of people, and religious practice, that were imposed right across the region. It seemed to me that in this atmosphere any meaningful safeguarding of mäshräp was simply unfeasible. I recommended against the inscription and wrote that in my view "local restrictions on a range of community-based religious activities and on large public gatherings could be expected to have a direct impact on the viability of mäshräp gatherings. . . It seems likely that this initiative will contribute to the promotion and preservation of folklorized representations of mäshräp traditions, while grassroots practice remains subject to the threats detailed above."

The Chinese submitting party wrote in their response that "in China, people of all ethnic groups fully enjoy the freedom in religious belief” but that mäshräp were a "space for traditional cultural practices instead of religious practices." The international jury responsible for assessing applications in that year accepted this representation, and the mäshräp was duly inscribed.

\section{A Joyful Song-and-Dance Gathering}

Since 2010 we can observe a number of trends in the safeguarding and transmission of mäshräp. The first is its thoroughgoing transformation into song and dance in the hands of the region's professional troupes. ${ }^{21}$ News reports welcoming the nomination proclaimed, fancifully, that the meaning of mäshräp in the Uyghur language was "joyful place of song-and-dance gathering." ${ }^{22}$ Mäshräp has now taken its place on the national stage alongside the Uyghur Muqam, the Kam Grand Song, and many other items of intangible heritage. The Xinjiang song-and-dance troupe and the Muqam Ensemble both developed large-scale mäshräp performances involving hundreds of dancers and musicians. Staged versions of mäshräp were screened monthly on Xinjiang TV stations. These productions draw on aspects of the music, games, and theatrical skits included in the thirty-one videos of regional mäshräp and utilize them as fresh material for the long-established project of China's professional minority song-and-dance 


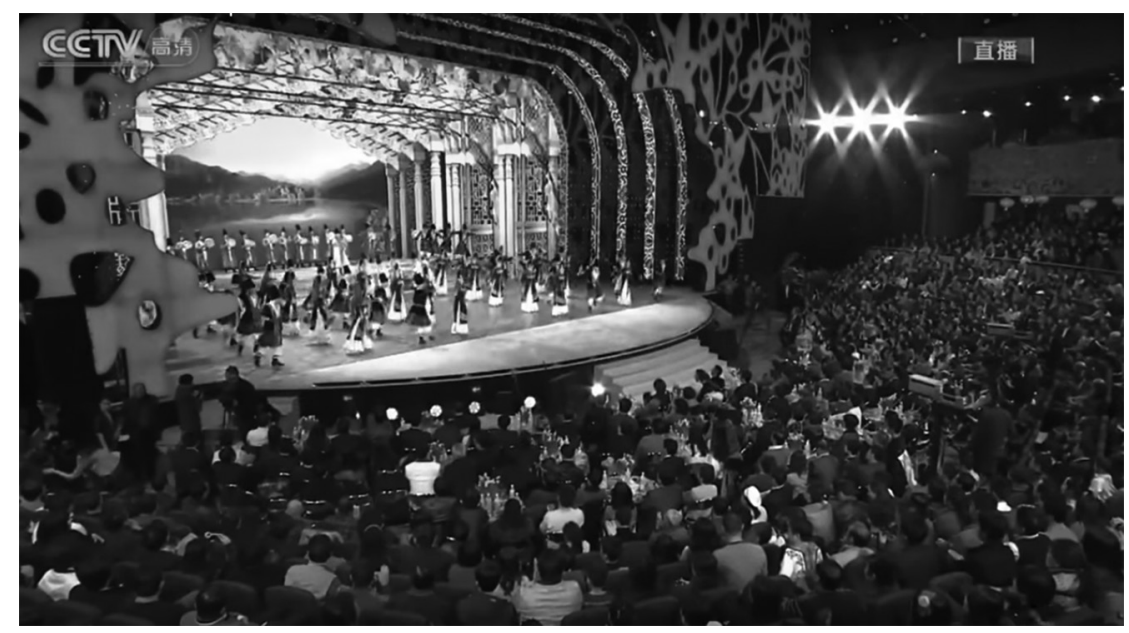

Figure 4. Dolan mäshräp performed on CCTV. Screenshot from YouTube.

troupes. Among many other appearances, mäshräp featured prominently in the CCTV Fourth Dance competition, and it was screened on national TV as part of the annual New Year Gala extravaganza, performed before an audience of China's national leaders.

The Xinjiang song-and-dance troupe's Dolan Mäshräp featured an adapted version of the Dolan Muqam, with new lyrics by the respected poet Mämtili Zunun, sung by the star singer Abdulla Abdurehim. At one level, with its massed ranks of smiling, costumed dancers, this production conformed to the wellrehearsed stereotype of minority performers serving up spectacle for the Han audience, displaying their harmonious presence at the heart of the multiethnic nation, but on another level it speaks to Uyghur nationalist sentiment. The new lyrics expressed a nostalgic identification with mäshräp by these urban cultural professionals; this is a proud and emotional re-creation of their Uyghur national heritage.

Ana yurtum ara tohpe miras bibaha mäshräp

Boghulghan däm nepeslärgä khipalik sap hawa mäshräp

Yänä yuksäl kuyashtäk parlisun pak ruhi millätning

Baghach eytsun bu alämni esil näghmä nawa mäshräp

Mäshräp, pride of our motherland, our precious heritage.

I draw breath in the pure health-giving air of the mäshräp.

Let the spirit of our nation shine strong like the sun.

Let the noble melody of the mäshräp embrace the whole world. 
These lyrics also salute the second trend in the safeguarding of the mäshräp: its deployment as an international cultural asset at work as part of state-led soft diplomacy initiatives. Thus in March 2013 the Xinjiang song-and-dance troupe performed their Dolan Mäshräp in Turkey just as China and Turkey were engaged in developing new trade and strategic partnerships. ${ }^{23}$ This agenda is also pursued - in a convergence of neoliberal values and state interests-by privately run but well-connected groups such as the Xinjiang Dilinaer Arts Troupe, which performed another newly choreographed show, Forever Mäshräp, in Hong Kong in 2013. Their promotional literature stated: "Xinjiang Dilinaer Arts Troupe aims at uniting various professional arts organizations and cultural arts workers to inherit and enhance the traditional arts of the minority groups in Xinjiang. Moreover, it also actively communicates with overseas arts organizations and artists to strengthen arts exchange activities and introduce the culture and arts of Xinjiang to the world." ${ }^{4}$

The rhetoric of "inherit and enhance" in this literature displays direct continuity with PRC cultural policy, which was developed on the basis of Mao's Talks at the Yan'an Forum in 1942 and which set cultural workers to "revise and enrich" China's traditions. There is also a high degree of continuity in practice; the development and rehearsal processes of Forever Mäshräp revealed in a 2013 media interview indicate the processes of bricolage involved. Pausing from arduous exercises accompanied by the piano, choreographer Ömärjan Mämtimin, freshly graduated from the Beijing Dance Academy, described how he had drawn together the special characteristics of no less than seven local traditions in his newly created but traditionally rooted mäshräp. ${ }^{25}$

As we have seen, transformations of this kind in designated items of intangible heritage are now very familiar across China, from Kunqu opera to Kam Grand Song. These items are also a well-recognized phenomenon of initiatives around the world. In contemporary scholarship, there is now much greater acceptance of these kinds of development, evolution, and change as part of the process of safeguarding. It is argued that where traditions are able to evolve to reflect new contexts and adopt new influences, this affords them greater resilience and adaptability; thus, it may be better for their vitality that they are allowed to do so. Many scholars now acknowledge that phenomena of cultural tourism and festivalization deserve consideration well beyond any dogmatic dismissal that they represent a less "authentic" tradition and therefore one of lesser value (Grant 2012). The principal problem with this view is that it places the emphasis of the safeguarding initiatives squarely on the discrete item of heritage rather than the people who create and maintain it and the immediate environment within which it thrived. This problem is certainly not unique to Xinjiang. Although the UNESCO convention pays close attention to the involvement and ownership of local communities, issues in this area are commonly 
reported (Seeger 2009; Foster 2015). Transmitters are often treated more as objects than as independent subjects free to develop and re-create their heritage on their own terms. They are too often deprived of agency and voice, leaving government bodies and heritage brokers to speak on their behalf (Kuah and Liu 2017; You 2015).

China's nominations are often characterized by a narrative of endangerment, loss, and threat due to the forces of Westernization and globalization. The UNESCO statement on mäshräp reads: "There are numerous factors endangering its viability, such as social changes resulting from urbanization and industrialization, the influence of national and foreign cultures, and the migration of young Uygur [sic] to cities for work. Frequency of occurrence and the number of participants are progressively diminishing, while the number of transmitters who understand the traditional rules and rich content of the event has sharply decreased from hundreds to tens." ${ }^{26}$ This narrative situates the Chinese state as protector of its national heritage in the face of modernization and foreign (cultural) incursions. The strategies that aim to "protect and promote" this heritage entail top-down initiatives that are implemented as a part of the wider sphere of state policies.

There are, of course, alternative ways of thinking about safeguarding. The rhetoric of ecology and sustainability places the emphasis on traditions as living cultural and creative practices rather than as heritage to be protected and preserved. Jeff Todd Titon (2009), for example, argues that theory and practice relating to sustainability should take into account the interdependence of the wider ecosystem in which the cultural practice is situated, using ecosystem as "a metaphor for an open, interdependent, co-evolving community." Titon presents an ideal model of local participatory art, gift exchanges within social networks, operating largely outside the neoliberal economic mainstream. Such ideals are clearly distant from the promotion of mäshräp described above, but they are clearly acknowledged goals in the UNESCO proclamation, which states that communities "play an important role in the production, safeguarding, maintenance and re-creation of the intangible cultural heritage, thus helping to enrich cultural diversity and human creativity" (introduction). "This intangible cultural heritage, transmitted from generation to generation, is constantly recreated by communities and groups in response to their environment, their interaction with nature and their history, and provides them with a sense of identity and continuity" (Article 2.1). ${ }^{27}$

The question of community engagement has been repeatedly raised in the discussions surrounding the UNESCO initiative. Anthony McCann cautions that "the creators and sustainers of folk and traditional cultures are clearly the most important constituency to be considered in formulating policy, for without them there is no living folklore and the crucial role it plays at many points 
in society."28 Richard Kurin has argued that communities should be "both the subject and object of safeguarding efforts" (2007:15). While mäshräp before the nomination adhered closely to Titon's model of local participatory art, the initiatives and developments described above placed mäshräp firmly in the hands of national-level, state-led organizations. So what has been happening at the grassroots level in Xinjiang since the nomination was approved?

\section{Seeking Grassroots Mäshräp}

In the summer of 2012, I returned to a village in southern Xinjiang I had visited several times during the 2000s. I had attended several mäshräp there in previous years, but in 2012 the yigit beshi said that they had not dared to organize a mäshräp since our last visit three years before because the local authorities would not allow it. "It's a shame," he said. "Our young people aren't learning how to play mäshräp anymore. They don't understand our values; they don't know how to behave." This conversation took place in the context of the tense climate of an antireligious extremism campaign that involved high levels of surveillance on many aspects of everyday life and bans on "illegal religious gatherings." ${ }^{29}$ It was apparent that the local authorities in this rural area were reluctant to sanction any forms of large-scale gatherings other than those directly organized by organs of the state.

On that occasion, emboldened by the presence of foreigners in the village and a visit by a well-known musician from Ürümchi, the yigit beshi decided to go ahead. They rigged up electric lights, laid out felt mats, and prepared the celebratory polo rice dish for the important guests. Several hundred villagers arrived on foot, in donkey carts, and on motorbikes. The musicians played, and the people danced. About two hours later, a group of Uyghur policemen arrived and told the organizers to halt the proceedings. At the same time, those guests who had come from the county town received calls from their work units telling them the event was not officially approved and that they should leave. There was a tense stand-off, then one of the policemen turned out to be a relative of one of the organizers, and a compromise was negotiated: the mäshräp could continue for one more hour but must disperse before midnight.

This, of course, is anecdotal evidence, but it is difficult for the international scholarly community to obtain more systematic independent evidence regarding the situation of grassroots mäshräp due to a law on intangible heritage adopted in 2011. This law requires that both foreign organizations and individuals receive approval for survey work from provincial-level agencies. Foreign organizations must collaborate with a Chinese partner, who must turn over copies of their research results to the agency that approved the project. ${ }^{30}$ Such tight controls on research mirror a general concern in China to control the flow of information to 
the outside world, while the perceived need for a new law specifically devoted to intangible heritage is suggestive of its importance in national policy.

What is observable, even without the benefit of systematic fieldwork, is the way that mäshräp have been harnessed at the local level in the service of specific state campaigns. The 2011 law requires that protecting intangible heritage be "beneficial to strengthening cultural identification with the Chinese nation, beneficial to upholding the unification of the state and ethnic unity, and promoting social harmony." Accordingly, a song-and-dance mäshräp was organized in Ghulja's town square in 2014 to celebrate "beautiful Ili, harmonious land of almonds." It was attended by a crowd of three thousand people. The performance aimed, according to media reports, to promote ethnic unity, social morality, and family values. ${ }^{31}$ In late 2014 online Uyghur-language media reported a "weekly mäshräp to tackle extremism" campaign in Aqsu. Ömärjan Hakim, governor of Awat County, reported on his blog that in order "to prevent extremist religious ideology from infiltrating society and to totally eliminate extremist religious activities we organized a series of mäshräp events. All nationalities attended the events and praised them. We listened to beautiful music, song, and dance and showed our determination to build our beautiful country."

Xinjiang Radio reported in April 2015 that 140 cadres had been sent to Poskam County to help tackle extremism through measures including a "weekly mäshräp to fulfill the people's spiritual lives.” The report featured photographs of a group of village musicians performing in front of the local police station. These accounts show that heritage initiatives were being deployed right at the heart of a radical mobilization of Uyghur society as part of the antireligious extremism campaign. ${ }^{32}$

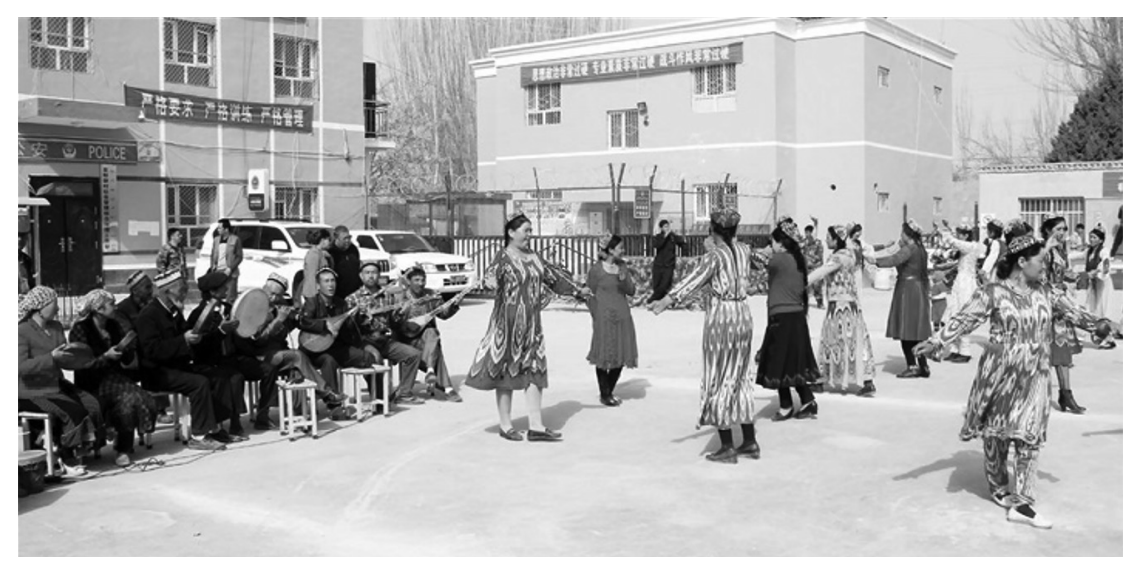

Figure 5. A "weekly mäshräp to counter extremism" in front of a police station in Poskam County. www.dihan.com.cn, 31 March 2015. 
A central aspect of UNESCO's safeguarding policy is the appointment of representative transmitters of the cultural heritage, key individuals who should be positioned in leading roles of any safeguarding initiative. What is the experience of these individuals in Xinjiang? Again, systematic evidence is hard to obtain, but in 2006 I interviewed two regional-level representative transmitters of the Dolan Mäshräp in Aqsu. They told me that the Aqsu Cultural Bureau formally recognized the cultural value of the Dolan Mäshräp in 2005 following a visit by members of the Xinjiang ICH Center. The officials selected sixteen people to perform regular mäshräp in the county town. In these mäshräp they played music and performed epizot (dramatic skits) about how the peasants were getting rich and about the importance of education and family planning. They were giving twice-monthly lessons to local boys, and the local government had started paying them a small monthly stipend of $135 \mathrm{RMB}$.

A 2015 media report featuring Obulhäsän Ähmät, a national-level representative intangible heritage bearer from Qaraqash County in Khotan, shows how representative transmitters were also mobilized as part of the antiextremism campaign. Best known for his mastery of the dastan (epic poem) Seyit Nochi, Obulhäsän was appointed a regional-level heritage bearer by the XUAR party committee propaganda bureau in 2007 . He started to take part in governmentorganized activities and became a grassroots propaganda study group member. In 2012 he was appointed national-level representative heritage bearer, with a substantial annual salary of 10,000 RMB (more than twice the average annual earnings for this impoverished county), and started teaching dastan to a class of local boys. According to the media report, this made him grateful to the party and the government, and he added extra content to his songs to promote ethnic unity and government policies and to tackle extremism. He began to perform on a weekly basis outside the mosque, advising people to be modern in their thinking and firmly oppose religious extremist thinking.

\section{Community Matters}

At the heart of the issues confronted in heritage policy lies the interpretation of the term "community", a notion that is central to many of UNESCO's proclaimed goals. When the UNESCO website proclaims that mäshräp provide communities with a sense of identity and continuity, what does "community" mean? Central to the understanding of intangible heritage in China is the formulation of community as a component of national identity. In this way, mäshräp is refigured as Chinese-Uyghur national heritage. In this formulation, the mäshräp project may be judged successful, a collaboration between Uyghur cultural leaders and the Chinese state, with considerable buy-in from Uyghur audiences. However, this view of heritage as a national resource or an asset enables governments 
to claim ownership of the heritage, transforming it into a state-led enterprise, encouraging its professionalization and commodification, and appropriating its symbolic power for the nation-state. An alternative view of community laid out by anthropologist Vered Amit lays emphasis on local identities and places, interaction, and shared experiences: "The emotive impact of community, the capacity for empathy and affinity ... arise not just out of an imagined community, but in the dynamic interaction between that concept and the actual and limited social relations and practices through which it is realized. People care because they associate the idea of community with people they know, with whom they have shared experiences, activities, places and/or histories" (2002:18). Amit's view of community forged in dynamic interactions echoes the ethnomusicological discussions of participatory music-making discussed above. If we adopt this view of community, then the safeguarding of mäshräp is more problematic, as current state security measures in Xinjiang are directly hostile to the sustainability of grassroots mäshräp because of its role in creating meaningful local community. When the Ili local government took such extreme measures to crack down on the new mäshräp in the 1990s, Dautcher suggests that "the state felt its legitimacy threatened by any form of community activism it did not initiate and control. ... [T] he state's vision of civic identity in Xinjiang had no place for the neighborhood as a basis for social belonging or grassroots social action" (2009:279).

China's "safeguarding" of the mäshräp thus involves separating the practice from its community roots and promoting versions that represent the national community at the expense of local communities. These processes form part of a wider context of state policies that are actively engaged in impeding and disrupting local forms of community organization and expression and replacing them with state-led initiatives. Intangible heritage initiatives in Xinjiang support professional folkloric representations of the heritage, and they press local artists who have been appointed as representative transmitters into the service of state propaganda campaigns. Arguably, through its inclusion of items like mäshräp on its heritage lists, UNESCO is symbolically sanctioning these policies. ${ }^{33} \mathrm{~A}$ 2018 report on Uyghur heritage by the US-based Uyghur Human Rights Project makes a series of recommendations to UNESCO, including the suggestion that UNESCO should "consider possible consequences for state parties to the Convention for the Safeguarding of the Intangible Cultural Heritage who fail to abide by international human rights instruments as referred to in its preamble, particularly when those rights violations touch on the very ICH items which UNESCO has listed as in need of protection." ${ }^{34}$

As Michael Foster (2015) notes, in theory a national signatory to the convention is technically in violation of international law if it fails to "take the necessary measures to ensure the safeguarding of the intangible cultural heritage present 
in its territory" (Article 11[a]). In practice, however, no sanctions for such a violation have been stipulated, and it is highly unlikely that any sanction would be applied against a major UNESCO partner such as China. This is unfortunate for Uyghur communities and also for the peace and stability of the region. The treatment of mäshräp is not only a problem due to abstract concerns for human rights and cultural sustainability. We should listen to the yigit beshi who complained that the youngsters in his village no longer understood their customs. By limiting independent local practice and harnessing cultural traditions to propaganda initiatives, state policies risk discrediting in the eyes of local communities the very cultural heritage that they purport to safeguard. It is precisely in situations like this-where young people are alienated from established community structures and practices - that they seek out new forms of association and absorb new values that may include the very "religious extremism" that China's campaigns are purportedly trying to root out.

\section{Notes}

1. In this article I follow the transliteration system for modern Uyghur now widely accepted in academic sources and as adopted in Komatsu et al. (2005).

2. UNESCO, “China: Meshrep," https://ich.unesco.org/en/USL/meshrep-00304 (accessed 17 April 2019).

3. 少数民族, shaoshu minzu, also translated as "ethnic minorities."

4. Influences of Sufism range from the continuing presence of organized Naqshbandi orders (Zarcone 2001) to popular practices of shrine pilgrimage (Harris and Dawut 2002; Thum 2014).

5. See Adrian Zenz, 2018, "New Evidence for China's Political Re-education Campaign in Xinjiang," China Brief 18(10), https://jamestown.org/program/evidence-for-chinas-political-re -education-campaign-in-xinjiang/ (accessed 17 August 2018).

6. The Dolan are a subgroup of the Uyghurs mainly living in the Yarkand and Tarim river areas. They may be the descendants of indentured serfs brought from the north of the region (Svanberg 1996).

7. Short video clips can be viewed here: http://www.musicofcentralasia.org/Tracks/Chapter/19 (accessed 17 April 2019).

8. My friend and colleague Rahile Dawut was detained without charge in December 2017 and remains in detention at the time of writing. See "Star Scholar Disappears as Crackdown Engulfs Western China," New York Times, 10 August 2018, https://www.nytimes.com/2018/08/10/world/ asia/china-xinjiang-rahile-dawut.html (accessed 17 April 2019).

9. https://ich.unesco.org/en/directives (accessed 17 April 2019).

10. https://www.culturalheritagechina.org/ (accessed 17 April 2019).

11. Literally, "goat dragging," a game played on horseback with a goat carcass, a tradition shared by several other ethnic groups and countries. The problems inherent in assigning a cultural practice to one ethnic group or one country have been frequently raised; see, for example, Carole Pegg on the Chinese/Mongolian khoomii controversy: http://www.akdn.org/akmi/musical-geographies -central-asia/carole-pegg (accessed 28 December 2017).

12. Li Changchun, Beijing, February 2006, http://www.chinaheritagequarterly.org/editorial .php?issue $=007$ (accessed 17 April 2019).

13. China Heritage Newsletter, 2 June 2005, China Heritage Project, ANU, http://www.china heritagequarterly.org/editorial.php?issue $=002$ (accessed 17 April 2019). 
14. CASS (26 April 2011) 为了保护和传承新疆维吾尔传统文化: 麦西热甫, http://cel.cssn .cn/fwzwhycbh/zgsj/201104/t20110426_2763739.shtml (accessed 17 April 2019).

15. See Jones (2003) and Harris (2008) for further discussion.

16. In the first round of the submission, the word mäshräp was infelicitously transliterated via the Chinese pinyin, maixilaipu, as "maxirap," prompting an American colleague involved in the examination process to call me up and ask, "Rachel, what on earth is this? It sounds like a kind of food wrapping!"

17. CASS, 26 April 2011, 为了保护和传承新疆维吾尔传统文化: 麦西热甫, http://cel.cssn .cn/fwzwhycbh/zgsj/201104/t20110426_2763739.shtml (accessed 17 April 2019).

18. Amnesty International Secretariat, 1999, Gross Violations of Human Rights in the Xinjiang Uighur Autonomous Region, http://www.refworld.org/pdfid/3ae6a9eb0.pdf (accessed 17 April 2019).

19. See Anthony Seeger's (2009) account of ICTM's involvement in the evaluation process from 2001 to 2005 and his recommendations concerning the evaluation process.

20. UNESCO, “China: Meshrep,” https://ich.unesco.org/en/USL/meshrep-00304 (accessed 17 April 2019).

21. Song and dance have a particular history in relation to China's minority peoples, whose musical traditions have been subject to extensive processes of cultural development since the midtwentieth century and whose smiling performers play an important role in symbolically upholding PRC rule over minority regions (Gladney 1997; Harris 2017).

22. http://www.china.com.cn/aboutchina/txt/2009-07/12/content_18117975.htm (accessed 17 April 2019).

23. Zan Tao, 25 October 2013, "An Alternative Partner to the West," Middle East Institute, http://www.mei.edu/content/alternative-partner-west-turkey\%E2\%80\%99s-growing-relations -china (accessed 17 April 2019).

24. 大型歌舞诗《永远的麦西来甫》4 July 2013, http://roll.sohu.com/20130704/ n380662887.shtml (accessed 17 April 2019).

25. Ibid.

26. UNESCO, “China: Meshrep," https://ich.unesco.org/en/USL/meshrep-00304 (accessed 17 April 2019).

27. UNESCO, "Text of the Convention for the Safeguarding of the Intangible Cultural Heritage," https://ich.unesco.org/en/convention (accessed 17 April 2019).

28. UNESCO, "Safeguarding Traditional Cultures: A Global Assessment," https://unesdoc .unesco.org/ark:/48223/pf0000132327 (accessed 17 April 2019).

29. For a firsthand account of the ways in which this campaign was impacting on daily life in rural Xinjiang in 2012, see Harris (2013).

30. Congressional-Executive Committee on China (16 February 2011), "Draft of Intangible Cultural Heritage Law Limits Research Activities," http://www.cecc.gov/publications/commission -analysis/draft-of-intangible-cultural-heritage-law-limits-research (accessed 17 April 2019).

31. 天山网: 新疆伊宁县举办大型歌舞麦西来甫 (11 August 2014), http://news.ts.cn/ content/2014-08/11/content_10387716_all.htm (accessed 17 April 2019).

32. Uyghur Human Rights Project, 2015, “Legitimizing Repression: China’s 'War on Terror' under Xi Jinping and State Policy in East Turkestan," https://docs.uhrp.org/pdf/Legitimizing -Repression.pdf (accessed 17 April 2015). For more details on the campaign's use of song and dance, see Harris (2017) and http://www.soundislamchina.org/?p=1053 (accessed 17 April 2019).

33 . Seeger $(2009,2015)$ emphasizes that UNESCO does not normally provide financial support for the action plans it ratifies. Once approved, the nation-state can apply for funding, but if it does not, there is no further control over how the action plan is implemented.

34. Uyghur Human Rights Project, 2018, "Extracting Cultural Resources: The Exploitation and Criminalization of Uyghur Cultural Heritage," https://docs.uhrp.org/pdf/CulturalResources IntangibleHeritage.pdf (accessed 17 August 2018). 


\section{References}

Abliz, Helimigul. 2009. "Uyghur mäshräp oyunliri heqide tetqiqat” [Study of Uyghur folk meshrep games]. Master's thesis, Xinjiang University.

Amit, Vered. 2002. Realizing Community: Concepts, Social Relationships and Sentiments. London: Routledge.

Amit, Vered, and Nigel Rapport. 2012. Community, Cosmopolitanism and the Problem of Human Commonality. London: Pluto Press.

Anderson, Benedict R. 1991. Imagined Communities: Reflections on the Origin and Spread of Nationalism. London: Verso.

Bellér-Hann, Ildikó. 1997. “The Peasant Condition in Xinjiang." Journal of Peasant Studies 24(4): $87-112$.

- 2008. Community Matters in Xinjiang 1880-1949: Towards a Historical Anthropology of the Uyghur. Leiden: Brill.

— . 2014. "The Bulldozer State: Chinese Socialist Development in Xinjiang." In Ethnographies of the State in Central Asia: Performing Politics, edited by Madeleine Reeves, Johan Rasanayagam, and Judith Beyer, 173-97. Bloomington: Indiana University Press.

Bohlman, Philip. 1988. The Study of Folk Music in the Modern World. Bloomington: Indiana University Press.

Bovingdon, Gardner. 2010. The Uyghurs: Strangers in Their Own Land. New York: Columbia University Press.

Brophy, David. 2016. Uyghur Nation: Reform and Revolution on the Russia-China Frontier. Cambridge, MA: Harvard University Press.

Chang, Jung-a. 2017. "From 'Folk Culture' to 'Great Cultural Heritage of China': The Aporia of the Quest for the Essence of Chinese Culture." In Intangible Cultural Heritage in Contemporary China: The Participation of Local Communities, edited by Khun Eng Kuah and Zhaohui Liu, 112-36. Abingdon: Routledge.

Chau, Adam Yuet. 2008. “The Sensorial Production of the Social." Ethnos 73(4): 485-504.

Dautcher, Jay. 2009. Down a Narrow Road: Identity and Masculinity in a Uyghur Community in Xinjiang China. Cambridge, MA: Harvard University Press.

Dawut, Rahile, and Yasin Muhpul. 2011. Uyghur mäshräp medeniyiti. 4 vols. Ürümchi: Shinjang guzel senet-foto suret neshriyati.

Foster, Michael Dylan. 2015. "UNESCO on the Ground: Local Perspectives on Global Policy for Intangible Cultural Heritage." Journal of Folklore Research 52(2-3): 143-56.

Gladney, Dru C. 1994. "Representing Nationality in China: Refiguring Majority/Minority Identities." Journal of Asian Studies 53(1): 92-123.

Grant, Catherine. 2012. "Rethinking Safeguarding: Objections and Responses to Protecting and Promoting Endangered Musical Heritage." Ethnomusicology Forum 21(1): 31-51.

Harris, Rachel. 2008. The Making of a Musical Canon in Chinese Central Asia: The Uyghur Twelve Muqam. Abingdon: Ashgate.

— . 2013. "Harmonizing Islam in Xinjiang: Sound and Meaning in Rural Uyghur Religious Practice." In On the Fringes of the Harmonious Society: Tibetans and Uyghurs in Socialist China, edited by Ildikó Bellér-Hann and Trine Brox, 293-317. Copenhagen: NIAS Press.

—. 2017. "Theory and Practice in Contemporary Central Asian Maqām." In Theory and Practice in the Music of the Islamic World: Essays for Owen Wright, edited by Rachel Harris and Martin Stokes, 215-35. Oxon: Routledge.

Harris, Rachel, and Rahilä Dawut. 2002. "Mazar Festivals of the Uyghurs: Music, Ritual and the Chinese State." British Journal of Ethnomusicology 11(1): 101-18.

Harris, Rachel, and Aziz Isa. 2011. "Invitation to a Mourning Ceremony: Perspectives on the Uyghur Internet." Inner Asia 13(1): 27-49. 
Howard, Keith. 2012. "East Asian Music as Intangible Cultural Heritage.” In Music as Intangible Cultural Heritage: Policy, Ideology and Practice in the Preservation of East Asian Traditions, edited by Keith Howard, 1-22. Abingdon: Ashgate.

Ingram, Catherine, with Wu Jialing, Wu Meifang, Wu Meixiang, Wu Pinxian, and Wu Xuegui. 2011. "Taking the Stage: Rural Kam Women and Contemporary Kam 'Cultural Development."' In Women, Gender and Rural Development in China, edited by Tamara Jacka and Sally Sargeson, 71-93. Cheltenham: Edward Elgar.

Jones, Stephen. 2003. "Reading between the Lines: Reflections on the Massive 'Anthology of Folk Music of the Chinese Peoples.” Ethnomusicology 47(3): 287-337.

— 2008. Junggu Uyghur mäshräpliri / Zhongguo weiwu'er maixilaipu. Ürümchi: Millätlär unsin näshriyati.

Komatsu, Hisao, et al., eds. 2005. Chuo-Yurashia wo shiru jiten [An encyclopedia of Central Eurasia]. Tokyo: Heibonsha.

Kuah Khun Eng and Zhaohui Liu. 2017. "Intangible Cultural Heritage in Contemporary China and Hong Kong: An Introductory Overview." In Intangible Cultural Heritage in Contemporary China: The Participation of Local Communities, edited by Khun Eng Kuah and Zhaohui Liu, 1-10. Abingdon: Routledge.

Kurin, Richard. 2007. "Safeguarding Intangible Cultural Heritage: Key Factors in Implementing the 2003 Convention." International Journal of Intangible Heritage 2:2-20.

Maimaiti, Aidiya. 2006. Yiwei renlei xuezhe shiye zhongde maixilaipu [An anthropologist's view of mäshräp]. Beijing: Minzu chubanshe.

McCann, Anthony, with James Early, Amy Horowitz, Richard Kurin, Leslie Prosterman, Anthony Seeger, and Peter Seitel. 2001. "The 1989 Recommendation Ten Years On: Towards a Critical Analysis." In Safeguarding Traditional Cultures: A Global Assessment, edited by Peter Seitel, 57-64. Washington, DC: Center for Folklife and Cultural Heritage, Smithsonian Institution.

McKhann, Charles F. 2010. "Naxi Religion in the Age of Tourism: Persistence and (Re)creation." In Faiths on Display: Religion, Tourism, and the Chinese State, edited by Tim Oakes and Donald S. Sutton, 183-210. Lanham, MD: Rowman \& Littlefield.

Millward, James A. 2009. "Introduction: Does the 2009 Ürümchi Violence Mark a Turning Point?" Central Asian Survey 28(4): 347-60.

Norton, Barley, and Naomi Matsumoto. 2018. "Introduction: Historical and Ethnographic Perspectives on Music as Heritage." In Music as Heritage: Historical and Ethnographic Perspectives, edited by Barley Norton and Naomi Matsumoto, 1-18. Abingdon: Routledge.

Ong, Min Yen. 2018. "Safeguarding Kunqu in the People's Republic of China." In Music as Heritage: Historical and Ethnographic Perspectives, edited by Barley Norton and Naomi Matsumoto. Abingdon: Routledge.

Pawan, Sawut, Rahile Dawut, and Saadet Kurban. 2017. "Uyghur Meshrep Culture and Its Social Function." Fourth World Journal 15(2): 81-89.

Rees, Helen. 2012. "Intangible Cultural Heritage in China Today." In Music as Intangible Cultural Heritage: Policy, Ideology and Practice in the Preservation of East Asian Traditions, edited by Keith Howard, 23-54. Abingdon: Ashgate.

_ 2016. "Environmental Crisis, Culture Loss, and a New Musical Aesthetic: China's 'Original Ecology Folksongs' in Theory and Practice." Ethnomusicology 60(1): 53-88.

Roberts, Sean. 1998. "Negotiating Locality, Islam, and National Culture in a Changing Borderlands: The Revival of the Mäshräp Ritual among Young Uighur Men in the Ili Valley." Central Asian Survey 17(4): 672-700.

- 2018. "The Biopolitics of China's 'War on Terror' and the Exclusion of the Uyghurs." Critical Asian Studies 50(2): 232-58.

Ruggles, D. Fairchild, and Helaine Silverman. “From Tangible to Intangible Heritage.” In Intangible Heritage Embodied, edited by D. Fairchild Ruggles and Helaine Silverman, 1-14. New York: Springer, 2009. 
Seeger, Anthony. 2009. "Lessons Learned from the ICTM .NGO) Evaluation of Nominations for the UNESCO Masterpieces of the Oral and Intangible Heritage of Humanity, 2001-5." In Intangible Heritage, edited by Laurajane Smith and Natsuko Akagawa, 112-28. London: Routledge.

_ 2015. "Understanding UNESCO: A Complex Organization with Many Parts and Many Actors." Journal of Folklore Research 52(2-3): 269-80.

Shelemay, Kay Kaufman. 2011. "Musical Communities: Rethinking the Collective in Music." Journal of the American Musicological Society 64(2): 349-90.

Silverman, Helaine, and Tami Blumenfield. 2013. "Cultural Heritage Politics in China: An Introduction." In Cultural Heritage Politics in China, edited by Tami Blumenfield and Helaine Silverman, 3-22. New York: Springer.

Smith Finley, Joanne. 2013. The Art of Symbolic Resistance: Uyghur Identities and Uyghur-Han Relations in Contemporary Xinjiang. Leiden: Brill.

Svanberg, Ingvar. 1996. "Ethnic Categorizations and Cultural Diversity in Xinjiang: The Dolans along the Yarkand River." Central Asiatic Journal 40(2): 260-82.

Svensson, Marina, and Christina Maags. 2018. "Mapping the Chinese Heritage Regime: Ruptures, Governmentality, and Agency." In Chinese Heritage in the Making: Experiences, Negotiations and Contestations, edited by Christina Maags and Marina Svensson, 11-38. Amsterdam: Amsterdam University Press.

Taylor, Timothy D. 2017. Music in the World: Selected Essays. Chicago: University of Chicago Press.

Thum, Rian. 2014. The Sacred Routes of Uyghur History. Cambridge, MA: Harvard University Press.

Titon, Jeff Todd. 2009. "Introduction to the Special Issue: Music and Sustainability." World of Music 51(1): 5-16.

- 2015. "Exhibiting Music in a Sound Community." Keynote address, CSTM conference, Sydney, Nova Scotia, Canada.

Turino, Thomas. 2008. Music as Social Life: The Politics of Participation. Chicago: University of Chicago Press.

Turner, Victor. (1969) 1995. The Ritual Process: Structure and Anti-structure. Abingdon: Routledge.

Williams, Brett. 2002. “The Concept of Community." Reviews in Anthropology 31(4): 339-50.

Wong, Isabel K. F. 2009. "The Heritage of Kunqu: Preserving Music and Theater Traditions in China." In Intangible Heritage Embodied, edited by D. Fairchild Ruggles and Helaine Silverman, 15-36. London: Springer.

You Ziying. 2015. "Shifting Actors and Power Relations: Contentious Local Responses to the Safeguarding of Intangible Cultural Heritage in Contemporary China." Journal of Folklore Research 52(2-3): 253-68.

Zarcone, Thierry. 2001. "The Sufi Networks in Southern Xinjiang during the Republican Regime (1911-1949): An Overview." In Islam in Politics in Russia and Central Asia: Early Eighteenth to Late Twentieth Centuries, edited by Stéphane A. Dudoignon and Komatsu Hisao, 119-32. London: Kegan Paul. 